\title{
FORMAÇÃO DE PROFESSORES E TECNOLOGIAS DIGITAIS
}

Em documentos oficiais da Educação, nos anos 1998, com os Parâmetros Curriculares Nacionais, as discussões sobre as tecnologias digitais chegaram ao contexto da Linguística Aplicada no Brasil, e às salas de aula de línguas para além das questões já convencionais, tratadas no âmbito da referida disciplina. Essas discussões ganharam força, a partir de 2017, com o lançamento da Base Nacional Comum Curricular do Ensino fundamental, que define, inclusive, um objetivo específico para gêneros textuais provenientes das práticas sociais do contexto digital. Ela lista uma quantidade significativa de habilidades para desenvolver em práticas de linguagem leitura, oralidade/escuta, produção de textos e análise linguística/semiótica, a partir de gêneros textuais provenientes dos campos de atuação (da vida cotidiana, da vida pública, das práticas de estudo e pesquisa, jornalístico midiático e artístico/literário).

Mas, por questões sociais, políticas, culturais e sanitárias, devido à propagação da Covid-19, que exige da humanidade um isolamento social e das escolas novas maneiras de pensar e agir em sala de aula, as discussões sobre as tecnologias digitais tomam novo formato, exigindo do professor outros saberes para ensinar e atuar junto à população. O ofício, a partir dos moldes centrados e dependentes da cultura digital, longe de ser uma prática exclusiva de escolarização, passa a ser monitorado de forma mais específica em outras instâncias como a familiar, por exemplo. De uma formação pautada na cultura do impresso, passa-se uma atuação que integra as tecnologias digitais em sua totalidade. Cenário desafiador e imprevisível, em termos de ensinoaprendizagem, contamos, por ora, com reflexões que perscrutam experiências e recortam particularidades motivadoras e instigantes, relatadas em torno do binômio formação docente e tecnologias digitais.

No contexto atual, pensar uma formação de professor que contemple o espaço sala de aula virtual, a interação didática, as estratégias de ensino e aprendizagem com base na realidade das práticas sociais mediadas pela tecnologia, parece ser uma necessidade concreta para, inclusive, assegurar a própria existência, de maneira significativa, da escola.

Apresentamos, nesta edição temática da Revista Leia Escola, oito artigos e uma entrevista que discutem a formação inicial e continuada de professores e o agir professoral em salas de aula da educação básica, mediado pelas tecnologias digitais. Pretendemos que esta edição possa realmente provocar uma discussão produtiva sobre a temática Formação de professores e tecnologias digitais.

Iniciamos nossas discussões com as contribuições de Fábio Lima, através de um questionamento muito pertinente sobre o perfil do professor de línguas: Você é tecnofóbico, tecnofílico ou tecnostênico? Para responder à sua pergunta, o pesquisador discute a relação que o professor mantém com as tecnologias digitais em sua vida pessoal e profissional. Em suas conclusões, ele aponta para uma ampliação do terceiro perfil do usuário. 
$\mathrm{Na}$ sequência, trazemos três artigos para discutirmos a formação do professor de línguas. Primeiramente, discutimos a formação inicial, através da participação de Luciane Puehler e Alice Matsuda. As pesquisadoras se situam no contexto do curso de Letras para questionarem como as tecnologias da informação e comunicação são contempladas na formação inicial do profissional de Letras, em suas grades curriculares, dos cursos presenciais de Universidades de Curitiba-PR. Elas ressaltam os gêneros textuais Fanfiction e o Podcast, na realidade das aulas de Literatura, no Ensino Médio. O segundo artigo marca as contribuições de Mitia Costa sobre a formação continuada do professor de língua portuguesa. Para dar conta de sua discussão, a pesquisadora elegeu o contexto do Mestrado Profissional em Letras, como um espaço de formação continuada, e apresentou uma proposta didático-pedagógica de letramento digital e crítico, desenvolvida por ela mesma em uma sala de aula do ensino fundamental. A autora ressalta, em seus resultados, que o uso pedagógico das novas tecnologias, além de ter contribuído para uma autorreflexão sobre o seu agir professoral, a sua formação, também favoreceu o trabalho colaborativo e estimulou os aprendizes a expressarem suas subjetividades, produzindo e utilizando arquivos de múltiplas semioses. Depois, mostramos uma formação de professor, sobre aplicativos móveis, realizada por Kadhiny Policarpo, Gabriela Nunes e Juliana Bergmann. Esta formação traz em evidência as tecnologias digitais de informação e comunicação postas como possibilidade de enfrentamento a problemas detectados na escola. O curso foi realizado pelas pesquisadoras e é apresentado no artigo, que também mostra os aplicativos móveis e suas potencialidades como possíveis recursos didáticos no ensino formal.

O bloco de artigos que segue focaliza ferramentas utilizadas pelos professores na escola básica. Neste momento, direcionamos nossas reflexões para a prática docente, para o agir professoral mediado por ferramentas digitais. A primeira contribuição é assinada por Jennifer Gramiani e Juliana Oliveira. Elas partem do princípio de que o educando escreve e lê no ciberespaço por intermédio das telas de seus smartphones, tablets, e-readers e demais artigos. Com base nisso, elas se propõem a debater como as práticas de escrita e leitura foram transfiguradas a partir do advento das TIC. O artigo seguinte apresenta a ferramenta google forms utilizada em situações de avaliações formativas. A discussão é realizada por Jacinta Rodrigues, Simone Aranha e Fabiana Freitas. Elas discutem a inserção de tecnologias digitais no contexto escolar, através de uma experiência exitosa realizada através do aplicativo Google Forms em avaliações formativas na prática de professores dos anos finais do ensino fundamental. A terceira contribuição é feita por Vilma Candido que nos apresenta a construção de um aplicativo assistivo que visa a dar auxílio as pessoas com autismo nas suas produções de textos. A construção do aplicativo se deu em um contexto de pesquisa que revelou que, apesar da variedade de recursos disponíveis nas plataformas móveis, são escassos aqueles que se propõem a auxiliar a construção de textos. $\mathrm{O}$ aplicativo possibilitou a obtenção de diferentes perspectivas a respeito do uso dos jogos na educação, além de contribuir no processo de desenvolvimento da habilidade de construção de narrativas. $O$ artigo que segue trata do aplicativo grapphia. Ele é de autoria de Vera Siqueira, Adriana Bodolay e Luciana Assis. O seu objetivo é apresentar resultados do uso da tecnologia como auxiliar do professor na sala de aula e facilitador do processo do ensinoaprendizagem da ortografia, no que se refere à memorização das palavras que possuem relação irregular entre grafema-fonema. As autoras apresentam resultados que nos 
permitem perceber uma melhoria da memorização das palavras, demonstrando que esse pode se tornar uma ferramenta pedagógica no ensino de ortografia.

Os artigos contemplam reflexões de autores, credenciados em instituições de vários estados brasileiros, reforçando a relevância temática e o interesse sistemático, em assuntos que expõe os interesses de quem se ocupa com a docência, enquanto espaço de profissionalização, caminhando lado a lado com as demandas da sociedade. Produzir conhecimento e partilhar resultados favorecem uma cultura letrada que precisa delimitar território como espaço de resistência e propagação de profissionais mais conscientes de seu papel social e cidadão.

Para encerrar esta discussão, trazemos uma entrevista realizada por Ângela Grillo e Michaela Pešková sobre o Ensino de língua e culturas estrangeiras em tempos de (pós) pandemia. As pesquisadoras apresentam-nos desafios e aprendizagens de educadores na China, que nos permitem ampliar a discussão inicial e provocar as leitoras e os leitores para uma necessidade de refletir sobre a urgência em repensar a formação de professores, a sala de aula, o ensino e aprendizagem, pontuando a forma de interação didática e a reconstrução de saberes em sala de aula de línguas.

A seção de temática livre é composta pelo texto de Poesia, resistência e esperança em Conceição Evaristo de Marcelo Medeiros da Silva e Josivânia da Cruz Vilela, os autores trazem uma leitura da poesia de Evaristo a partir da categoria "esperança", no sentido emprestado a ela por Paulo Freire em Pedagogia da Esperança (2000), e da concepção de resistência, como concebida por Alfredo Bosi (2000) em O ser e o tempo da poesia.Nada mais apropriado para fechar esse último número de 2020 e esperançar junto ao conceito de Paulo Freire, mas, não sem esquecer a urgente necessidade de resistência tal como assinalada por Alfredo Bosi.

Organizadoras

Dora Riestra - Universidade Nacional do Rio Negro - Argentina

Eulália Vera Lúcia Fraga Leurquin - UFC

Williany Miranda Silva - UFCG

Dezembro de 2020 